\title{
Analisis Proses Produksi Menggunakan Teori Antrian Secara Analitik dan Simulasi
}

\author{
Rika Listiyani ${ }^{1}$, Lilik Linawati ${ }^{2}$, Leopoldus Ricky Sasongko ${ }^{3}$ \\ 1,2,3) Fakultas Sains dan Matematika, Jurusan Matematika, Universitas Kristen Satya Wacana \\ Jln. Diponegoro 52-60 Salatiga 50711 \\ Email: rikalistiyani96@gmail.com ${ }^{1}$, lilik.linawati@staff.uksw.edu ${ }^{2}$, \\ leopoldus.sasongko@staff.uksw.edu ${ }^{3}$
}

\begin{abstract}
The focus of this research is to analyze the production process queuing system at one of the stages of production of swiftlet nest in analytical and simulation. The purpose of this research is to obtain the model and characteristics of the queue system at the Finishing-2. The analysis uses data on the rate of arrival and the rate of service based on real observation and determines the probability distribution of data between arrival time and service time using the Easyfit 3.0 program, to get the model of the queuing system is obtained. After the model obtained, analytic and simulation analysis is carried out using the Queuing System Simulation (QSS) module in the WINQSB software. The results of the queuing system characteristics in the analytical and simulation have a significant difference, because the distribution of time between arrivals and service times used in analytical calculations is $G$ (general), while the simulation uses a distribution that refers to a particular type of distribution according to the results of the Easyfit program. Simulation is carried out with the FIFO and SIRO queue disciplines. The simulation results show that $91 \%$ of the characteristics of the queue system in the two queue disciplines do not have a significant difference. Moreover, it has also been done a comparison between the characteristics of the queuing system in two different work areas namely Room $A$ and Room B\&C, based on the simulation results, the results show $58 \%$ of the characteristics of the queuing system have a significant difference, this is due to differences in service time between the two work areas. Thus the purpose of this research has been achieved which is obtained by the queue model (G/G/c):(FIFO/ $/ \infty)$, and also obtained system performance improvements, in the form of waiting time in the queue where the waiting time in Room $B \& C$ is smaller than Room $A$.
\end{abstract}

Keywords: Queuing, Arrival, Service, Production, Simulation.

\section{Abstrak}

Fokus penelitian ini menganalisis sistem antrian proses produksi pada salah satu tahap produksi sarang burung walet secara analitik dan simulasi. Tujuan penelitian ini adalah untuk mendapatkan model dan karakteristik sistem antrian pada tahap Finishing-2. Analisis menggunakan data laju kedatangan dan laju pelayanan berdasarkan pengamatan real, serta penentuan distribusi probabilitas data waktu antar kedatangan dan waktu pelayanan menggunakan program Easyfit 3.0, untuk mendapatkan model dari sistem antriannya. Setelah model antrian didapatkan, dilakukan analisis secara analitik dan simulasi menggunakan modul Queuing System Simulation (QSS) pada software WINQSB. Hasil analisis karakteristik sistem antrian secara analitik dan simulasi memiliki perbedaan yang signifikan, disebabkan distribusi waktu antar kedatangan dan waktu pelayanan pada penghitungan analitik adalah $G$ (general), sedangkan pada simulasi menggunakan distribusi yang merujuk pada satu jenis distribusi tertentu sesuai hasil pada program Easyfit. Simulasi dilakukan masingmasing dengan disiplin antrian FIFO dan SIRO. Hasil simulasi menunjukkan 91\% karakteristik sistem antrian kedua disiplin antrian tersebut tidak memiliki perbedaan yang signifikan. Juga dilakukan perbandingan karakteristik sistem antrian di dua ruang kerja yang berbeda, yaitu Ruang A dan Ruang B\&C, dan berdasarkan hasil simulasi menunjukkan 58\% karakteristik sistem antrian memiliki perbedaan yang signifikan, hal ini disebabkan adanya perbedaan waktu pelayanan antara kedua ruang tersebut. Dengan demikian, tujuan

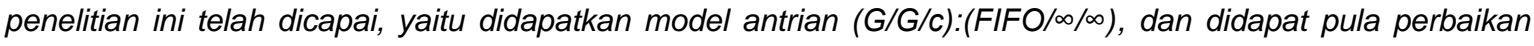
kinerja sistem, berupa waktu tunggu dalam antrian dimana waktu tunggu pada Ruang B\&C lebih kecil daripada Ruang A.

Kata Kunci : Antrian, Kedatangan, Pelayanan, Produksi, Simulasi. 


\section{Pendahuluan}

Pada salah satu perusahaan yang bergerak di bidang pengolahan sarang burung walet dari bahan baku hingga menghasilkan barang jadi, menggunakan sistem manual, yaitu setiap tahap pengerjaan dilakukan oleh tenaga manusia. Berdasarkan pengamatan pada proses produksi, terdapat permasalahan yaitu terjadinya penumpukan barang di tahap-tahap tertentu, yang mana dapat menjadi salah satu faktor yang memperlambat proses produksi dan dapat berakibat pada penurunan kualitas sarang burung walet, karena bahan terlalu lama berada pada proses produksi. Adanya penumpukan barang di suatu tahap mengindikasikan adanya suatu sistem antrian dalam proses produksi tersebut. Permasalahan antrian biasanya disebabkan oleh kebutuhan akan layanan barang melebihi kapasitas atau fasilitas pelayanannya, sehingga barang yang datang tidak bisa langsung mendapatkan layanan (Wibowo, 2010). Salah satu permasalahan antrian terjadi pada tahap Finishing-2, yaitu tahap terakhir dari proses produksi sarang burung walet, yang diindikasikan dengan adanya penumpukan barang setiap harinya. Penumpukan barang menyebabkan rata-rata waktu proses produksi sarang burung walet pada tahap ini melebihi target yang diinginkan perusahaan.

Tujuan penelitian ini adalah untuk mendapatkan model dan karakteristik sistem antrian pada tahap Finishing-2. Penelitian sebelumnya terhadap analisis sistem antrian pada proses produksi oleh Mikowati (2010) dengan menerapkan metode simulasi antrian untuk menganalisis kinerja dari sistem antrian dan mengembangkan model antrian untuk saran perbaikan. Hal tersebut menjadi dasar bagi penulis untuk menganalisis sistem antrian Finishing-2. Jika dalam penelitiannya, Mikowati menggunakan simulasi antrian untuk menganalisis sistem proses produksi, maka pada penelitian ini penulis menambahkan analisis karakteristik sistem secara analitik yang kemudian akan dianalisis perbedaan karakteristik sistem secara analitik dan simulasi. Analisis perbedaan dimaksudkan untuk mendapatkan cara yang paling tepat untuk mendapatkan karakteristik sistem antrian pada tahap Finishing-2.

\section{Metode Penelitian}

Teori Antrian adalah studi matematis yang berkaitan dengan keadaan yang berhubungan dengan segala aspek orang/barang menunggu untuk dilayani. Teori Antrian pertama kali diperkenalkan oleh Agner Krarup Erlang, seorang ahli Matematika dari Denmark pada tahun 1917 (Taylor III, 2004). Teori antrian digunakan untuk menganalisis kinerja/karakteristik sistem antrian yang ada dengan menggunakan model antrian. Model antrian digunakan untuk mempresentasikan berbagai macam sistem antrian yang ada dalam sistem nyata. Proses antrian digambarkan pada Gambar 1.

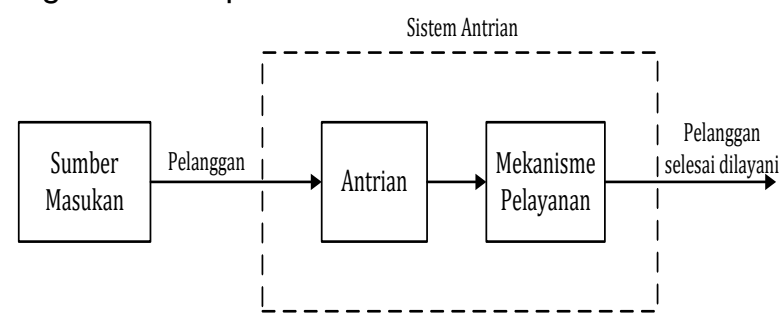

Gambar 1. Proses Antrian Dasar (Lieberman, 2008)

Terdapat beberapa faktor penting dalam melakukan analisis terhadap antrian yaitu:

1. Laju kedatangan dan laju pelayanan Laju kedatangan $(\lambda)$ adalah rata-rata jumlah kedatangan pelanggan ke suatu fasilitas pelayanan selama periode waktu tertentu, sedangkan laju pelayanan $(\mu)$ adalah rata-rata jumlah pelanggan yang dapat dilayani selama periode waktu tertentu (Taylor III, 2004). Laju pelayanan harus lebih besar dari laju kedatangan agar tidak terjadi antrian pelanggan yang tidak terhingga, dengan $c \mu>\lambda$ dimana $c$ adalah jumlah pelayan. Jika kondisi tersebut terpenuhi maka sistem antrian berada dalam kondisi steady state.

2. Distribusi waktu antar kedatangan dan waktu pelayanan

Waktu antar kedatangan adalah waktu kedatangan antara pelanggan satu dengan pelanggan berikutnya. Waktu pelayanan adalah lamanya waktu yang dibutuhkan pelanggan saat mendapatkan pelayanan. Waktu antar kedatangan dan waktu pelayanan perlu ditentukan jenis distribusi probabilitas dari sebaran datanya untuk menentukan model sistem antrian. 
3. Populasi pelanggan

Populasi pelanggan atau dapat disebut juga populasi sumber adalah total jumlah pelanggan yang membutuhkan pelayanan dari waktu ke waktu (Lieberman, 2008). Populasi pelanggan dapat diasumsikan tak berhingga/tak terbatas atau berhingga/terbatas.

4. Kapasitas Antrian

Kapasitas antrian merupakan jumlah maksimum pelanggan yang diizinkan berada didalam sistem antrian.

5. Disiplin antrian

Disiplin antrian menunjukkan aturan urutan kedatangan dan urutan pelayanan pelanggan. Disiplin antrian diantaranya First In First Out (FIFO), Last In First Out (LIFO), Priority Service (PS), Service In Random Order (SIRO)

6. Mekanisme pelayanan

Menurut Lieberman (2008), mekanisme pelayanan meliputi jumlah fasilitas pelayanan dan jumlah jalur pelayanan pararel (pelayan) pada setiap fasilitas pelayanan.

Berikut notasi dan terminologi untuk analisis karakteristik model antrian menurut Lieberman (2008):

$\lambda$ : laju kedatangan.

$\mu \quad$ : laju pelayanan.

C : jumlah pelayan (jalur pelayanan pararel) dalam sistem antrian.

$\mathrm{P}_{0}$ : probabilitas tidak ada pelanggan dalam sistem antrian.

$L_{s} \quad$ : ekspektasi jumlah pelanggan dalam sistem antrian.

$\mathrm{L}_{q} \quad$ : ekspektasi panjang antrian (selain pelanggan yang sedang dilayani).

$W_{s}$ : waktu tunggu dalam sistem (termasuk waktu pelayanan) untuk setiap individu pelanggan.

$\mathrm{W}_{\mathrm{q}}$ : waktu tunggu dalam antrian (diluar waktu pelayanan) untuk setiap individu pelanggan.

Beberapa model antrian dasar yang umum digunakan:

a. Model Antrian (M/M/C) : (FIFO/ / )

Model antrian ini dalam Taylor III (2004) disebut model antrian pelayanan ganda. Model antrian ini memiliki sejumlah $c$ pelayan $(c=1,2,3, \ldots)$. Disiplin antrian pada model ini adalah FIFO, waktu antar kedatangan berdistribusi Eksponensial, waktu pelayanan Eksponensial, serta kapasitas antrian dan populasi pelanggan tidak terbatas.

Rumus untuk mencari karakteristik sistem antrian pada model ini adalah:

$P_{0}=\left(\left(\sum_{n=0}^{n=c-1} \frac{1}{n !}\left(\frac{\lambda}{\mu}\right)^{n}\right)+\frac{1}{c !}\left(\frac{\lambda}{\mu}\right)^{c}\left(\frac{c \mu}{c \mu-\lambda}\right)\right)^{-1}$

Pers. 1

$L_{s}=\frac{\lambda \mu\left(\frac{\lambda}{\mu}\right)^{c}}{(c-1) !(c \mu-\lambda)^{2}} P_{0}+\frac{\lambda}{\mu}$

Pers. 2

$L_{q}=L_{s}-\frac{\lambda}{\mu}$

Pers. 3

$W_{q}=\frac{L_{q}}{\lambda}$

Pers. 4

$W_{s}=\frac{L_{s}}{\lambda}$

Pers. 5

b. Model Antrian (G/G/C) : (FIFO/ / )

Menurut Gross dan Harris (1998) dalam Artiguna (2014) menyatakanmodel antrian ini memiliki sebaran waktu kedatangan berdistribusi umum (general), waktu pelayanan berdistribusi umum (general), dengan jumlah fasilitas pelayanan sebanyak $c ; c=1,2,3, \ldots$ Disiplin antrian dalam model ini adalah FCFS, dengan kapasitas antrian dalam sistem tak hingga, dan memiliki populasi pelanggan tak hingga. Rumus untuk mencari karakteristik sistem antrian pada model ini adalah:

$\mathrm{r}=\frac{\lambda}{\mu}$

Pers. 6

$\rho=\frac{\lambda}{c \mu}$

Pers. 7

$L_{q}=\left(\frac{r^{c} \rho}{c !(1-\rho)^{2}}\right) P_{0} \frac{\mu^{2} \operatorname{var}(t)+\operatorname{var}\left(t^{\prime}\right) \lambda^{2}}{2}$

Pers. 8

dengan $\operatorname{var}(t)=$ variansi waktu pelayanan dan $\operatorname{var}\left(t^{\prime}\right)=$ variansi waktu antar kedatangan

$L_{s}=L_{q}+\frac{\lambda}{\mu}$

Pers. 9

$W_{q}=\frac{L_{q}}{\lambda}$

Pers. 10

$W_{s}=W_{q}+\frac{1}{\mu}$

Pers. 11

\section{Simulasi}

Simulasi adalah suatu metodologi untuk melakukan percobaan menggunakan model dari suatu sistem nyata yang bertujuan untuk mempelajari dan memahami sifat-sifat, tingkah laku, dan karakteristik operasinya (Siagian, 2006). Dengan simulasi dapat dibuat sistem alternatif yang meningkatkan kinerja dari sistem 
lama. Simulasi memiliki 3 komponen penting, yaitu penentuan jenis distribusi dan generated values, bookeeping aspect of simulation analysis, dan output analysis (Shortle, 2018). Berikut langkah-langkah dalam simulasi menurut Siagian (2006):

1. Menentukan sistem atau persoalan yang hendak disimulasi.

2. Mengembangkan model simulasi yang hendak digunakan.

3. Menguji model dan membandingkan tingkah laku hasil simulasi dengan tingkah laku dari sistem nyata (validasi model simulasi).

4. Merancang percobaan-percobaan simulasi.

5. Menjalankan simulasi dan analisis data.

\section{Software WINQSB (Quantity System for Business for Windows)}

Terdapat 2 modul dalam software WINQSB untuk menganalisis sistem antrian, yaitu Queuing Analysis (QA) dan Queuing System Analysis (QSS). Perbedaan antara keduanya hanya terletak pada pembentukan model antriannya. Pada modul QSS, model sistem antrian harus dibentuk sendiri oleh pengguna program sedangkan pada modul QA model sistem antrian sudah tersedia. Modul QSS lebih tepat digunakan untuk sistem antrian pada proses produksi yang memiliki aliran antrian/model antrian yang bervariasi.

\section{Uji Mann-Whitney}

Uji Mann-Whitney dilakukan untuk menguji kemampuan generalisasi rata-rata dua sampel/populasi yang tidak berkorelasi (Sugiyono, 2015), jika kedua populasi tersebut tidak berdistribusi normal. Menurut Setiawan (2017), pada uji ini dilakukan penggabungan 2 data sampel menjadi satu sampel $X_{1}, X_{2}, \ldots, X_{m}$, $Y_{1}, \quad Y_{2}, \ldots, Y_{n}$ dengan masing-masing data berdistribusi $F$ dan $G$. Berikut ini langkahlangkah dalam uji Mann-Whitney:

1. Menentukan hipotesis yang akan diuji yaitu $H_{0}: F=G$, melawan $H_{1}: F \neq G$.

2. Memilih tingkat signifikansi a yang digunakan.

3. Statistik uji yang digunakan adalah $\begin{array}{ll}U_{1}=m n+\frac{1}{2} m(n+1)-S_{1}, & \text { Pers.12 } \\ U_{2}=m n+\frac{1}{2} m(n+1)-S_{2}, & \text { Pers.13 }\end{array}$ dengan $S_{1}=$ jumlah rangking kelompok 1 , $S_{2}=$ jumlah rangking kelompok 2 .
4. Jika nilai $m$ atau $n$ lebih kecil dari 20 , maka hipotesis nol ditolak jika $U_{\text {hitung }}=$ $\min \left(U_{1}, U_{2}\right)$ lebih kecil dari $U$ tabel MannWhitney. Jika nilai $m$ atau $n$ lebih besar dari 20, maka statistik uji yang digunakan pada langkah 3 adalah

$Z=\frac{\left|U-\frac{n \cdot m}{2}\right|}{\sqrt{\frac{n \cdot m(n+m+1)}{12}}}$

Pers.14

dimana $\mathrm{H}_{0}$ diterima jika nilai $Z$ lebih kecil dari nilai $\mathrm{Z}$ tabel.

Uji Mann-Whitney juga dapat dilakukan dengan bantuan beberapa program komputer, salah satunya program SPSS. Penentuan keputusan penerimaan atau penolakan hipotesis dalam SPSS dapat dilihat dari nilai $U$ atau nilai Asymtop Sig. pada tabel Test Statistics (tabel dari hasil analisis nilai kualitas). Apabila signifikansi dibawah tingkat signifikansi a maka $\mathrm{H}_{1}$ diterima dan $\mathrm{H}_{0}$ ditolak (Sugiyono, 2015).

\section{Pengumpulan Data}

Penelitian ini dilakukan di suatu perusahaan pengolahan sarang burung walet yang berlokasi di Provinsi Jawa Tengah, secara khusus pada lini produksi Finishing-2 pada bulan Agustus sampai dengan Oktober 2018. Objek yang diamati yaitu barang produksi berupa sarang burung walet sebagai pelanggan dalam sistem antrian, pekerja sebagai pelayan, serta faktor lain dalam sistem antrian seperti kapasitas antrian, disiplin antrian, dan mekanisme antrian. Teknik pengumpulan data dengan cara melakukan pengamatan dan pencatatan langsung dalam proses produksi tahap Finishing-2 dan melakukan wawancara dengan pihak perusahaan.

Data yang dikumpulkan yaitu data primer dan sekunder. Data primer meliputi waktu mulai dan waktu selesai suatu barang dilayani pada setiap sub-tahap Finishing-2 sebagai data waktu pelayanan pada tanggal 26 Agustus-8 Oktober 2018. Data waktu kedatangan diambil dari waktu selesai pada data waktu pelayanan di sub-tahap sebelumnya. Data sekunder meliputi jumlah jam kerja, informasi pembagian ruang kerja, data pekerja/pelayan, dll.

Pada tahap Finishing-2, pelayanan dibagi menjadi 2 ruang kerja yaitu pelayanan untuk barang yang berasal dari ruang $A$ dan pelayanan dari barang yang berasal dari ruang B\&C. 
Barang yang berasal dari ruang $\mathrm{A}$ akan mendapat pelayanan oleh beberapa orang yang khusus menangani barang dari ruang tersebut, begitu pula dengan Ruang B\&C. Tidak terdapat perbedaan jenis barang yang diproses antara kedua ruang tersebut.

Setiap ruang melalui proses produksi yang sama, seperti digambarkan pada Gambar 2.

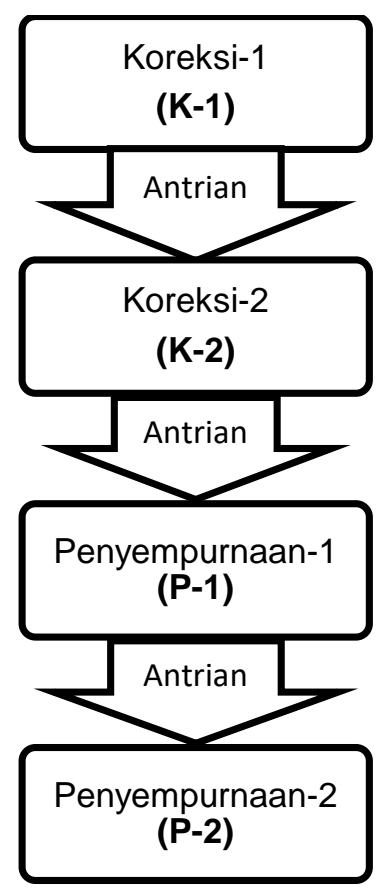

\section{Gambar 2. Proses produksi tahap Finishing-2}

Pada penelitian ini, analisis antrian dilakukan terpisah setiap sub-tahap Finishing-2 baik di Ruang A maupun Ruang B\&C, masingmasing yaitu Sistem Antrian pada Koreksi-2 (K2), Penyempurnaan-1 (P-1) dan Penyempurnaan-2 (P-2).

\section{Langkah Penelitian}

Langkah-langkah penelitian seperti ditampilkan pada Gambar 3.

Satuan hitung untuk barang adalah kotak, tanpa memperhatikan jumlah sarang burung walet yang ada didalam kotak, sedangkan satuan waktu yang digunakan adalah jam.

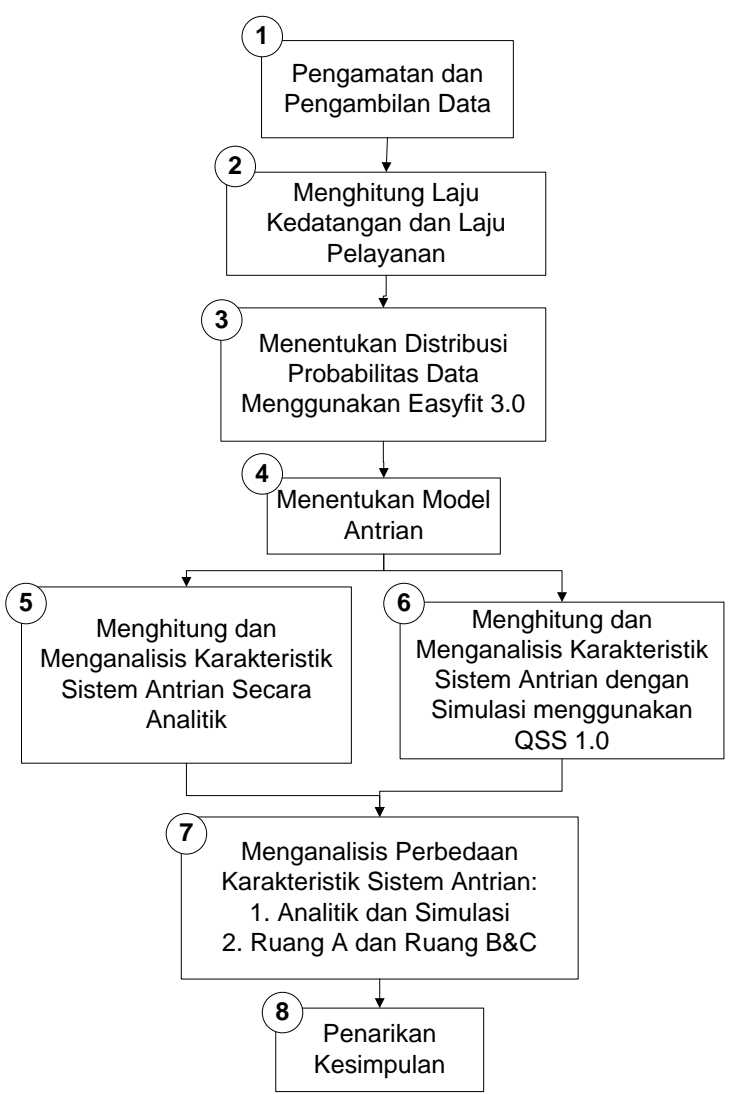

Gambar 3. Langkah penelitian

\section{Hasil dan Pembahasan}

\section{Laju Kedatangan dan Laju Pelayanan}

Rekapitulasi penghitungan laju kedatangan dan laju pelayanan masing-masing sub-tahap disajikan pada Tabel 1.

Tabel 1. Laju kedatangan $(\lambda)$ dan laju pelayanan $(\mu)$

\begin{tabular}{|c|c|c|c|c|c|}
\hline \multicolumn{3}{|c|}{ Sub-tahap } & K-2 & P-1 & P-2 \\
\hline \multirow{2}{*}{ 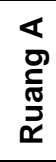 } & \multicolumn{2}{|c|}{$\lambda($ kotak/jam) } & 1,087 & 1,036 & 1,127 \\
\hline & \multicolumn{2}{|c|}{$\mu$ (kotak/jam) } & 15,341 & 2,216 & 1,744 \\
\hline \multirow{4}{*}{ 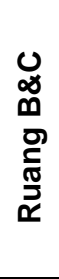 } & \multicolumn{2}{|c|}{$\lambda($ kotak/jam) } & 2,028 & 1,964 & 2,134 \\
\hline & \multirow{3}{*}{$\begin{array}{c}\boldsymbol{\mu} \\
\text { (kotak } \\
\text { /jam) }\end{array}$} & $\begin{array}{c}\text { Pelayan } \\
1\end{array}$ & 14,567 & 2,065 & 2,697 \\
\hline & & $\begin{array}{c}\text { Pelayan } \\
2\end{array}$ & & 1,884 & 2,894 \\
\hline & & $\begin{array}{c}\text { Rata- } \\
\text { rata }\end{array}$ & 14,567 & 1,974 & 2,795 \\
\hline
\end{tabular}

Pada setiap sub-tahap di Ruang A, laju pelayanan $(\mu)$ lebih besar daripada laju kedatangan $(\lambda)$, sedangkan di Ruang $B \& C$ setiap sub-tahap memenuhi syarat $c \mu>\lambda$, sehingga masing-masing sub-tahap dikedua ruang tersebut memenuhi syarat steady state. 


\section{Hasil Uji Distribusi Data}

Hasil uji distribusi data waktu antar kedatangan disajikan pada Tabel 2, sedangkan hasil uji distribusi waktu pelayanan disajikan pada Tabel 3.

Tabel 2. Hasil uji distribusi waktu antar kedatangan

\begin{tabular}{|c|c|l|l|}
\hline Ruang & $\begin{array}{c}\text { Sub- } \\
\text { tahap }\end{array}$ & Distribusi & \multicolumn{1}{|c|}{ Parameter } \\
\hline \multirow{4}{*}{ A } & K-2 & Lognormal & $\begin{array}{l}\sigma=0,79869 \\
\mu=-0,37633 \\
\gamma=0\end{array}$ \\
\cline { 2 - 4 } & $\mathbf{P}-1$ & Weibull & $\begin{array}{l}\alpha=0,74566 \\
\beta=0,81959 \\
\gamma=0\end{array}$ \\
\cline { 2 - 4 } & P-2 & Lognormal & $\begin{array}{l}\sigma=0,8632 \\
\mu=-0,45947 \\
\gamma=-0,00442\end{array}$ \\
\hline \multirow{5}{*}{ B\&C } & K-2 & Gamma & $\begin{array}{l}\alpha=1,7794 \\
\beta=0,28351 \\
\gamma=0\end{array}$ \\
\cline { 2 - 4 } & P-1 & Lognormal & $\begin{array}{l}\sigma=1,3426 \\
\mu=-1,5\end{array}$ \\
\cline { 2 - 4 } & P-2 & Gamma & $\begin{array}{l}\alpha=0,82885 \\
\beta=0,57096 \\
\gamma=0\end{array}$ \\
\hline
\end{tabular}

Tabel 3. Hasil uji distribusi waktu pelayanan

\begin{tabular}{|c|c|c|c|}
\hline Ruang & $\begin{array}{l}\text { Sub- } \\
\text { tahap }\end{array}$ & Distribusi & Parameter \\
\hline \multirow{3}{*}{ A } & $\mathrm{K}-2$ & Gamma & $\begin{array}{l}\alpha=1,7794 \\
\beta=0,28351 \\
y=0\end{array}$ \\
\hline & P-1 & Lognormal & $\begin{array}{l}\sigma=1,3426 \\
\mu=-1,5\end{array}$ \\
\hline & P-2 & Gamma & $\begin{array}{l}\alpha=0,82885 \\
\beta=0,57096 \\
y=0\end{array}$ \\
\hline \multirow{4}{*}{$B \& C$} & K-2 & Weibull & $\begin{array}{l}\alpha=1,7501 \\
\beta=0,07544 \\
\gamma=0\end{array}$ \\
\hline & \multirow[t]{2}{*}{ P-1 } & $\begin{array}{l}\text { Pelayan } 1 \text { : } \\
\text { Weibull (3P) }\end{array}$ & $\begin{array}{l}\alpha=1,4818 \\
\beta=0,48127 \\
y=0,06645\end{array}$ \\
\hline & & $\begin{array}{l}\text { Pelayan } 2 \text { : } \\
\text { Normal }\end{array}$ & $\begin{array}{l}\sigma=0,30739 \\
\mu=0,71838\end{array}$ \\
\hline & P-2 & $\begin{array}{l}\text { Pelayan 1: } \\
\text { Gamma (3P) }\end{array}$ & $\begin{array}{l}\alpha=1,6297 \\
\beta=0,20734 \\
y=0,06574\end{array}$ \\
\hline
\end{tabular}

Hasil distribusi waktu antar kedatangan maupun waktu pelayanan pada setiap subtahap Finishing-2 tidak mengikuti distribusi eksponensial, sehingga untuk model antrian dasar mengikuti distribusi umum (Genera).

\section{Penyusunan Model Antrian}

Dengan menggunakan asumsi bahwa ukuran populasi pelanggan dan batasan maksimal pelanggan dalam sistem antrian tidak terbatas, serta hasil uji distribusi waktu antar kedatangan dan waktu pelayanan, maka diperoleh model antrian untuk analisis secara analitik disajikan pada Tabel 4.

Tabel 4. Model antrian setiap sub-tahap Finishing-2

\begin{tabular}{|c|c|c|}
\hline \multirow{2}{*}{$\begin{array}{c}\text { Sub- } \\
\text { tahap }\end{array}$} & \multicolumn{2}{|c|}{ Model } \\
\cline { 2 - 3 } K-2 & Ruang A & Ruang B\&C \\
\hline P-1 & $\begin{array}{c}(\mathrm{G} / \mathrm{G} / 1): \\
(\mathrm{FIFO} / \infty / \infty)\end{array}$ & $\begin{array}{c}(\mathrm{G} / \mathrm{G} / 1): \\
(\mathrm{FIFO} / \infty / \infty)\end{array}$ \\
\hline P-2 & $\begin{array}{c}(\mathrm{G} / \mathrm{G} / 1): \\
(\mathrm{FIFO} / \infty / \infty)\end{array}$ & $\begin{array}{c}(\mathrm{G} / \mathrm{G} / 2): \\
(\mathrm{FIFO} / \infty / \infty)\end{array}$ \\
\hline \multicolumn{2}{|c}{$(\mathrm{G} / \mathrm{G} / 1):$} & $\begin{array}{c}(\mathrm{G} / \mathrm{G} / 2): \\
(\mathrm{FIFO} / \infty / \infty)\end{array}$ \\
\hline
\end{tabular}

Jenis distribusi G (General) sesuai dengan hasil uji distribusi pada Tabel 2 dan Tabel 3, sedangkan jumlah pelayan sesuai dengan jumlah pekerja/pelayan pada masingmasing sub-tahap di Finishing-2, dengan disiplin antrian FIFO sesuai dengan model dasar yang diasumsikan di dasar teori. Kapasitas antrian dan populasi pelanggan diasumsikan tidak terbatas.

\section{Karakteristik Sistem Antrian Secara Analitik}

Berdasarkan model yang sudah diperoleh serta laju kedatangan dan laju pelayanan yang sudah dicari sebelunya, dapat dihitung besaran-besaran karakteristik sistem antrian sesuai dengan Pers. 6 - Pers. 11. Hasil penghitungan karakteristik sistem antrian secara analitik dapat dilihat pada Tabel 5 .

Tabel 5. Karakteristik sistem antrian tahap Finishing-2 hasil analitik

\begin{tabular}{|c|c|c|c|c|c|}
\hline $\begin{array}{c}\text { Sub- } \\
\text { Taha } \\
\text { p }\end{array}$ & $\begin{array}{c}\text { Ruan } \\
\text { g }\end{array}$ & $L q$ & Ls & $W q$ & Ws \\
\hline \multirow{2}{*}{ K-2 } & A & $\begin{array}{r}0,00 \\
3\end{array}$ & $\begin{array}{r}0,07 \\
4\end{array}$ & $\begin{array}{r}0,00 \\
2\end{array}$ & $\begin{array}{r}0,06 \\
8\end{array}$ \\
\hline & B\&C & $\begin{array}{r}0,01 \\
1\end{array}$ & 0,15 & $\begin{array}{r}0,00 \\
5\end{array}$ & $\begin{array}{r}0,07 \\
4\end{array}$ \\
\hline \multirow{2}{*}{ P-1 } & A & $\begin{array}{r}0,93 \\
8 \\
\end{array}$ & $\begin{array}{r}1,40 \\
6 \\
\end{array}$ & $\begin{array}{r}0,90 \\
6 \\
\end{array}$ & $\begin{array}{r}1,35 \\
7 \\
\end{array}$ \\
\hline & $B \& C$ & $\begin{array}{r}0,46 \\
5 \\
\end{array}$ & 1,46 & $\begin{array}{r}0,23 \\
7 \\
\end{array}$ & $\begin{array}{r}0,74 \\
3 \\
\end{array}$ \\
\hline \multirow{2}{*}{ P-2 } & A & $\begin{array}{r}0,77 \\
4\end{array}$ & 1,42 & $\begin{array}{r}0,69 \\
7\end{array}$ & 1,26 \\
\hline & B\&C & $\begin{array}{r}0,10 \\
9\end{array}$ & $\begin{array}{r}0,87 \\
2 \\
\end{array}$ & $\begin{array}{r}0,05 \\
1\end{array}$ & $\begin{array}{r}0,40 \\
9\end{array}$ \\
\hline
\end{tabular}

Nilai karakteristik sistem antrian terkecil ada pada sub-tahap Koreksi-2 baik di Ruang A dan Ruang B\&C. Hal ini berarti panjang antrian 
dan jumlah barang dalam sistem lebih sedikit dari pada Penyempurnaan-1 dan Penyempurnaan-2, begitu pula waktu tunggu barang dalam antrian maupun dalam sistem pada sub-tahap Koreksi-2 memiliki waktu lebih sedikit dari Penyempurnaan-1 dan Penyempurnaan-2.

\section{Simulasi Sistem Antrian}

Pada simulasi ini, selain dilakukan simulasi dengan disiplin antrian FIFO (selanjutnya disebut Simulasi FIFO) sesuai dengan asumsi model antrian pada penghitungan analitik, juga dilakukan simulasi dengan disiplin antrian SIRO (selanjutnya disebut Simulasi SIRO) yang merupakan disiplin antrian yang juga sering terjadi pada kenyataannya. Karakteristik sistem antrian hasil Simulasi FIFO disajikan pada Tabel 6 sedangkan Simulasi SIRO pada Tabel 7.

Tabel 6. Karakteristik sistem antrian Finishing-2 hasil Simulasi FIFO

\begin{tabular}{|c|c|c|c|c|c|}
\hline \multicolumn{2}{|c|}{$\begin{array}{c}\text { Karakteris } \\
\text { tik Sistem } \\
\text { Antrian }\end{array}$} & $L q$ & Ls & $W q$ & Ws \\
\hline $\mathrm{K}-2$ & \multirow{3}{*}{ 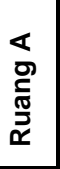 } & 0,00003 & 0,08213 & 0,00008 & 0,08758 \\
\hline P-1 & & 0,62410 & 1,18770 & 0,45660 & 0,98050 \\
\hline P-2 & & 0,35170 & 0,93850 & 0,26410 & 0,80650 \\
\hline K-2 & \multirow{3}{*}{ 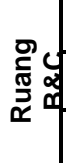 } & 0,00366 & 0,13786 & 0,00174 & 0,06915 \\
\hline P-1 & & 0,56330 & 1,71650 & 0,23690 & 0,80300 \\
\hline P-2 & & 0,06220 & 0,77680 & 0,03200 & 0,40350 \\
\hline
\end{tabular}

Tabel 7. Karakteristik sistem antrian Finishing-2 hasil Simulasi SIRO

\begin{tabular}{|c|c|c|c|c|c|}
\hline \multicolumn{2}{|c|}{$\begin{array}{c}\text { Karakteris } \\
\text { tik Sistem } \\
\text { Antrian }\end{array}$} & $L q$ & Ls & $W q$ & Ws \\
\hline K-2 & \multirow{3}{*}{ 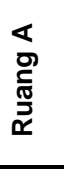 } & 0,00010 & 0,08359 & 0,00009 & 0,06897 \\
\hline P-1 & & 1,09440 & 1,46800 & 0,46220 & 0,97470 \\
\hline P-2 & & 0,32630 & 0,92990 & 0,23350 & 0,78710 \\
\hline K-2 & \multirow{3}{*}{ 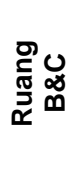 } & 0,06023 & 0,13979 & 0,00132 & 0,07508 \\
\hline P-1 & & 0,53570 & 1,68960 & 0,22070 & 0,80450 \\
\hline P-2 & & 0,07030 & 0,75630 & 0,03510 & 0,42400 \\
\hline
\end{tabular}

Validasi model simulasi dilakukan dengan membandingkan waktu pelayanan hasil simulasi FIFO (Ws dikurangi $W q$ ) dengan waktu pelayanan pada sistem nyata. Berikut disajikan hasil validasi berupa nilai Asymp. Sig hasil uji Mann-Whitney pada Tabel 8.
Tabel 8. Hasil validasi waktu pelayanan simulasi dan sistem nyata

\begin{tabular}{ccc}
\hline Ruang & Simulasi & Nilai \\
\hline \multirow{3}{*}{ A } & K-2 & 0,939 \\
& P-1 & 0,669 \\
& P-2 & 0,213 \\
\hline \multirow{3}{*}{ B\&C } & K-2 & 0,526 \\
& P-1 & 0,139 \\
& P-2 & 0,885 \\
\hline
\end{tabular}

Berdasarkan hasil uji Mann-Whitney pada Tabel 8, dengan tingkat kepercayaan 95\%, nilai Asymp. Sig. seluruhnya lebih dari 0,05 , sehingga dapat disimpulkan tidak ada perbedaan signifikan antara waktu pelayanan pada simulasi dan sistem nyata.

\section{Perbedaan Karakteristik Sistem Antrian Simulasi FIFO dan Simulasi SIRO}

Untuk mengetahui perbedaan karakteristik sistem antrian hasil Simulasi FIFO dan Simulasi SIRO, maka dilakukan uji MannWhitney untuk mengetahui ada tidaknya perbedaan rata-rata hasil simulasi dari masingmasing karakteristik sistem antrian pada Simulasi FIFO dan Simulasi SIRO. Data yang diuji adalah 50 data sampel dari hasil simulasi masing-masing sub-tahap Finishing-2. Hipotesis yang digunakan dalam uji MannWhitney ini adalah

$\mathrm{H}_{0}$ : Tidak ada perbedaan rata-rata $(L q, L s, W q$, atau $W s$ ) pada Simulasi FIFO dan Simulasi SIRO

$\mathrm{H}_{1}$ : Ada perbedaan rata-rata $(L q, L s, W q$, atau Ws) pada Simulasi FIFO dan Simulasi SIRO

Nilai $\alpha$ yang digunakan adalah 0.05 . Jika nlai Asymp. Sig.> 0,05, maka $\mathrm{H}_{0}$ diterima, sedangkan jika nilai Asymp. Sig. $<0,05$ maka $\mathrm{H}_{0}$ ditolak dan $\mathrm{H}_{1}$ diterima. Hasil uji Mann-Whitney untuk Simulasi FIFO dan Simulasi SIRO dapat dilihat pada Tabel 9.

Dari Tabel 9, dapat diketahui bahwa 2 dari 24 karakteristik sistem antrian yang diuji memiliki nilai Asymp. Sig.<0,05, yang artinya lebih dari $91 \%$ karakteristik sistem antrian pada Simulasi FIFO dan SIRO tidak memiliki perbedaan yang signifikan. 
Tabel 9. Hasil uji Mann-Whitney Simulasi FIFO dan SIRO pada masing-masing karakteristik sistem antrian

\begin{tabular}{ccrrrr}
\hline \multirow{2}{*}{$\begin{array}{c}\text { Ruan } \\
\mathbf{g}\end{array}$} & $\begin{array}{c}\text { Simula } \\
\text { si }\end{array}$ & \multicolumn{4}{c}{ Nilai Asymp. Sig. } \\
\cline { 3 - 6 } & $\mathbf{L q}$ & \multicolumn{1}{c}{$\boldsymbol{c s}$} & $\boldsymbol{W q}$ & $\boldsymbol{W s}$ \\
\hline & & 1,00 & 0,75 & 1,00 & 0,94 \\
& $\mathrm{~K}-2$ & 0 & 1 & 0 & 0 \\
$\mathrm{~A}$ & & $\mathbf{0 , 0 0}$ & 0,34 & $\mathbf{0 , 0 2}$ & 0,54 \\
& $\mathrm{P}-1$ & $\mathbf{5}$ & 5 & $\mathbf{2}$ & 0 \\
& & 0,62 & 0,15 & 0,92 & 0,79 \\
& $\mathrm{P}-2$ & 5 & 0 & 9 & 3 \\
\hline & & 0,94 & 0,59 & 0,97 & 0,58 \\
& $\mathrm{~K}-2$ & 7 & 8 & 0 & 3 \\
$\mathrm{~B} \& \mathrm{C}$ & & 0,52 & 0,52 & 0,45 & 0,18 \\
& $\mathrm{P}-1$ & 6 & 1 & 4 & 9 \\
& & 0,94 & 0,33 & 0,64 & 0,64 \\
& $\mathrm{P}-2$ & 2 & 6 & 0 & 4 \\
\hline
\end{tabular}

Dapat disimpulkan dari hasil uji MannWhitney, simulasi dengan disiplin antrian FIFO maupun simulasi dengan disiplin antrian SIRO pada sistem antrian tahap Finishing-2 memiliki karakteristik sistem yang hampir sama. Artinya, kedua disiplin antrian tersebut dapat diterapkan pada sistem antrian pada tahap Finishing-2. Namun demikian terdapat kelebihan dan kelemahan dari masing-masing disiplin antrian tersebut jika diterapkan pada tahap Finishing-2.

\section{Perbedaan Karakteristik Sistem Antrian Secara Analitik dan Hasil Simulasi Antrian}

Analisis perbedaan hasil penghitungan karakteristik sistem antrian secara analitik dan Simulasi FIFO dilakukan dengan cara mencari selisih besaran karakteristik sistem antrian dari keduanya. Pada bagian ini akan difokuskan analisis perbedaan waktu tunggu dalam antrian $(W q)$ hasil analitik dan simulasi. Selisih waktu tunggu dalam antrian $(W q)$ tersebut disajikan pada Tabel 10.

Tabel 10. Selisih $W q$ hasil analitik dan Simulasi FIFO

\begin{tabular}{|c|c|c|r|r|}
\hline \multirow{2}{*}{ Ruang } & $\begin{array}{c}\text { Sub- } \\
\text { tahap }\end{array}$ & $\begin{array}{c}\text { Selisih } \\
\mathbf{W q} \\
\text { (jam) }\end{array}$ & $\begin{array}{c}\text { Rata-rata } \\
\text { Waktu } \\
\text { Pelayanan } \\
\text { (jam) }\end{array}$ & $\begin{array}{c}\text { Prosent } \\
\text { ase (\%) }\end{array}$ \\
\hline \multirow{2}{*}{$\mathrm{A}$} & $\mathrm{K}-2$ & 0,0019 & 0,0679 & 2,83 \\
\cline { 2 - 5 } & $\mathrm{P}-1$ & 0,4494 & 0,5222 & $\mathbf{8 6 , 0 7}$ \\
\cline { 2 - 5 } & $\mathrm{P}-2$ & 0,4329 & 0,5907 & $\mathbf{7 3 , 2 9}$ \\
\hline \multirow{3}{*}{ B\&C } & $\mathrm{K}-2$ & 0,0033 & 0,0732 & 4,45 \\
\cline { 2 - 5 } & $\mathrm{P}-1$ & 0,0001 & 0,5531 & 0,02 \\
\cline { 2 - 5 } & $\mathrm{P}-2$ & 0,0190 & 0,3937 & 4,84 \\
\hline
\end{tabular}

Pada Tabel 10, kolom selisih $W q$ adalah selisih waktu tunggu barang hasil penghitungan analitik dan simulasi, rata-rata waktu pelayanan adalah rata-rata pelayanan dari data waktu pelayanan real, sedangkan prosentase adalah prosentase perbandingan selisih $W q$ dan ratarata waktu pelayanan.Nilai prosentase menunjukkan tingkat perbedaan dari waktu tunggu barang dalam antrian hasil penghitungan analitik dan simulasi terhadap waktu pelayanan. Jika prosentase kecil, maka selisih waktu antara hasil analitik dan Simulasi FIFO tidak signifikan, sehingga diasumsikan tidak berpengaruh pada pelayanan, sebaliknya jika prosentase besar maka selisih waktunya signifikan. Dari Tabel 10 dapat dilihat prosentase besar terdapat pada sub-tahap Penyempurnaan-1 dan Penyempurnaan-2 di Ruang A, yaitu $86 \%$ dan $73 \%$. Artinya perbedaan waktu tunggu antara hasil penghitungan analitik dan simulasi memiliki perbedaan yang signifikan.

\section{Perbedaan Karakteristrik Sistem Antrian Ruang A dan Ruang B\&C}

Untuk mengetahui perbedaan karakteristik sistem antrian Ruang A dan Ruang B\&C, maka dilakukan uji Mann Whitney untuk mengetahui ada tidaknya perbedaan rata-rata hasil simulasi dari masing-masing karakteristik sistem antrian pada kedua ruang tersebut. Data yang diuji adalah 50 data sampel dari hasil Simulasi SIRO masing-masing sub-tahap Finishing-2 Ruang A dan Ruang B\&C. Hipotesis yang digunakan dalam uji Mann-Whitney ini adalah:

$H_{0}$ : Tidak ada perbedaan rata-rata $(L q, L s, W q$, atau $W s$ ) pada Ruang $A$ dan Ruang B\&C $\mathrm{H}_{1}$ : Ada perbedaan rata-rata $(L q, L s, W q$, atau Ws) pada Ruang A dan Ruang B\&C

Nilai a yang digunakan adalah 0.05 . Jika nlai Asymp. Sig.> 0,05, maka $\mathrm{H}_{0}$ diterima, sedangkan jika nilai Asymp. Sig. $<0,05$ maka $\mathrm{H}_{0}$ ditolak dan $\mathrm{H}_{1}$ diterima. Hasil uji Mann-Whitney untuk Ruang $A$ dan Ruang B\&C dapat dilihat pada Tabel 11.

Tabel 11. Hasil uji Mann-Whitney Ruang A dan Ruang B\&C pada masing-masing karakteristik sistem sntrian

\begin{tabular}{|c|c|c|c|c|}
\hline \multirow{2}{*}{ Simulasi } & \multicolumn{4}{|c|}{ Nilai Asymp. Sig. } \\
\cline { 2 - 5 } & $\mathbf{L q}$ & $\mathbf{L s}$ & $\mathbf{W q}$ & $\mathbf{W s}$ \\
\hline $\mathbf{K}-\mathbf{2}$ & 1,000 & $\mathbf{0 , 0 0 0}$ & 1,000 & 0,899 \\
\hline $\mathbf{P}-\mathbf{1}$ & $\mathbf{0 , 0 0 0}$ & 0,815 & $\mathbf{0 , 0 0 0}$ & $\mathbf{0 , 0 0 0}$ \\
\hline $\mathbf{P}-\mathbf{2}$ & $\mathbf{0 , 0 0 0}$ & 0,188 & $\mathbf{0 , 0 0 0}$ & $\mathbf{0 , 0 0 0}$ \\
\hline
\end{tabular}

Dari Tabel 11, dapat diketahui bahwa 7 dari 12 karakteristik sistem antrian yang diuji 
memiliki nilai Asymp. Sig.<0,05, yang artinya lebih dari $58 \%$ rata-rata karakteristik sistem antrian pada Ruang A dan Ruang B\&C memiliki perbedaan yang signifikan.

Salah satu karakteristik sistem yang memiliki perbedaan rata-rata hasil simulasinya adalah waktu tunggu barang dalam antrian $(W q)$ dan waktu tunggu dalam sistem $(W s)$. Selisih karakteristik sistem antrian tersebut antara Ruang A dan Ruang B\&C disetiap subtahap Finishing-2 disajikan pada Tabel 12. Satuan waktu $W q$ dan $W s$ diubah menjadi menit.

Tabel 12. Selisih Wq dan Selisih Ws pada Ruang A dan Ruang B\&C dalam satuan menit

\begin{tabular}{ccc}
\hline Sub-Tahap & $\boldsymbol{W q}$ & $\boldsymbol{W s}$ \\
\hline K-2 & $-0,07$ & $-0,37$ \\
P-1 & 14,49 & 10,21 \\
P-2 & 11,91 & 21,79 \\
\hline
\end{tabular}

Tanda (-) pada Tabel 12 menunjukkan bahwa waktu tunggu pada Ruang B\&C lebih besar daripada Ruang A. Dapat dilihat bahwa selisih waktu pelayanan ( $W q$ dikurangi $W s$ ) antara Ruang $A$ dan Ruang B\&C pada sub-tahap Penyempurnaan- 1 sebesar \pm 4 menit dan pada sub-tahap Penyempurnaan-2 sebesar \pm 10 menit.

\section{Kesimpulan}

Berdasarkan uraian dari hasil penelitian dan pembahasan, dapat disimpulkan sebagai berikut:

- Sistem antrian pada tahap Finishing-2 mengikuti model antrian

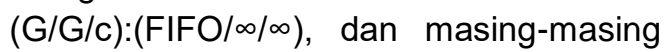
sub-tahap pada Finishing-2 memenuhi syarat steady state.

- Analisis karakteristik sistem antrian Finishing 2 dilakukan secara analitik dan simulasi dengan modul QSS 1.0 pada software WINQSB. Hasil analisis perbedaan antara keduanya menunjukkan analisis secara simulasi lebih menggambarkan sistem antrian nyata karena menggunakan hasil uji distribusi waktu antar kedatangan dan waktu pelayanan yang spesifik merujuk pada satu jenis distribusi tertentu daripada analisis secara analitik yang distribusinya diasumsikan General.
- Simulasi dengan disiplin antrian FIFO maupun disiplin antrian SIRO menunjukkan hasil karakteristik sistem antrian yang hampir sama (tidak memiliki perbedaan yang signifikan).

- Hasil analisis perbedaan karakteristik sistem antrian antara Ruang A dan Ruang B\&C menunjukkan beberapa karakteristik mempunyai perbedaan yang signifikan, diantaranya panjang antrian, waktu tunggu dalam antrian dan waktu tunggu dalam sistem pada sub-tahap Penyempurnaan-1 dan Penyempurnaan-2. Waktu tunggu dalam antrian dan pada Ruang B\&C lebih kecil daripada Ruang $A$, hal ini disebabkan oleh waktu pelayanan di Ruang B\&C lebih cepat daripada Ruang A.

\section{Daftar Pustaka}

Artiguna, P.P., Sugito, \& Hoyyi, A. (2014). Analisis Sistem Antrian pada Layanan Pengurusan Pasport di Kantor Imigrasi Kelas I Semarang. Jurnal Gaussian, Vol. 3( 4), 801-810.

Lieberman, Hillier. (2008). Introduction to Operation Research (8th ed.). Inc. New York: The McGraw-Hill Companies.

Mikowati, Linda. (2010). Analisis Sistem Antrian pada Industri Pengolahan Roti (Studi Kasus di PT Nippon Indosari Corpindo). Skripsi. Jurusan Matematika Fakultas Teknologi Petanian. Institut Pertanian Bogor.

Setiawan, A., (2017). Analisis Data Statistik. Salatiga: Tisara Grafika.

Shortle, J.F dkk. (2018). Fundamentals of Queueing Theory (5th ed.). Inc: John Wiley and Sons.

Siagian, P. (2006). Penelitian Operasional, Jakarta: Penerbit Universitas Indonesia (UIPress).

Sugiyono, Susanto, A. (2015). Cara Mudah Belajar SPSS dan Lisrel Teori dan Aplikasi untuk Analisis Data Penelitian. Bandung: Alfabeta.

Taylor III, B.W. (2004). Introduction to Management Science (8th ed.). Upper Saddle River, New Jersey: Pearson Education-Prentice Hall,.

Wibowo, A., Ramadian, D. (2010). Model Simulasi Kinerja Produksi Teh untuk Minimisasi Work-In-Process, Jurnal Optimasi Sistem Industri, Vol. 9(1), 7-12. 
Halaman ini sengaja dikosongkan

This page is intentionally left blank 